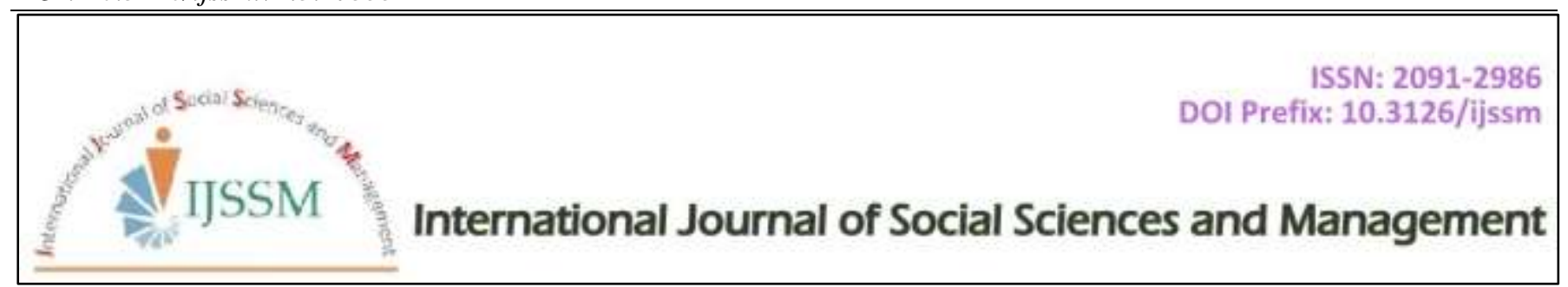

Research Article

\title{
The Market-Oriented Management Style of Private Vocational Schools in Complying with the Labor Market in Southern Thailand
}

\author{
Phakan Tantikornphan* and Sasiwemon Sukkabot
}

Faculty of Management Sciences, Prince of Songkha Unviersity, Songkhla, 90110, Thailand

* Corresponding author’s email: phakan_tg@hotmail.com

\begin{abstract}
The aim of this paper is to research the market-oriented management style of Private Vocational Schools in complying with the labor market in Southern Thailand. This research employed mixed methods as the research methodology, as detailed below, by interviewing ten education executive managers of PrivateVocational Schools and ten general executive managers of employers, using 356 sample questionnaires and reviewing 41 schools in Nakhonsrithammarat, Songkhla and Suratthani provinces. This is based on the growth rate and expansion of industry during the year 2015. The research period is from July to December 2015. (Source: Federation of Industries, 2014). The research found that the important factors were curriculum, quality of graduates, personal practical skills and their making community relations with the local society, compensation and qualification, budget implementation, location and physical characteristics, network construction and participation, public relations, setting up a standard for the learner employers, and their evaluation from employers. In addition, after exploring and confirming via factor analysis, it was found that the market-oriented management style (of private vocational schools) contained five factors including setting up standard and evaluation network construction and public relations with other organizations, public relations with other schools, physical characteristics and location,participationof the employers to develop learner skills. connected with market mix and the 8Ps.
\end{abstract}

Keywords: Market-mix; Job market; Private vocational school.

\section{Introduction}

The current labor problems are the production or creation of qualified workers to meet the needs of business enterprises, or the job market, does not comply with the requirements of the job market. A World Bank Organization survey found that Thailand is experiencing a shortage of labor quantity and quality (Kaewcharoen, 2014).

In order to solve this problem, quality workers must begin at the vocational school, to have the capacity and ability to produce labor and meet the needs of the labor market. Private vocational education institutions do not comply with the requirements of the labor market, this has been shown by related research such as private vocational school strategies in Chiang Mai (Wuteay, 2009) elements of the marketing strategies that influence the success of private schools, (Ungsujinda, 2010) marketing strategies of Private Vocational Schools in Thailand (Akradate $\mathbf{J}$ and Sudaporn S, 2013).

The research discussed the issues of development policies in schools and monitoring teaching, quality management and management components of the success of Private Vocational Schools. However, there is no research on the management style to comply with the labor market in Southern Thailand. Thus, the researcher highlights the importance of the market management to infer the form of solution including labor and the quality of students in private vocational institutions.

\section{Objective}

This research is aimed to investigate the market-oriented management style of Private Vocational Schools in complying with the labor market in Southern, Thailand.

\section{Literature Review}

\section{Concept and Current Status of Job Market}

"Job Market", Reynold (1980) and Lipsey R and Lipsey G (1996) said that the job market refers to the center of trading and industrial center handicrafts including agricultural fields in their territory, in terms of the labor market conditions in the country. Chalamwong (2014) said that between 2009-2014, the volatile nature has always been a 
problem for several reasons, including the economic downturn in Europe and America. It has hugely affected the exports of Thailand. Moreover, political issues have severely impacted the economy and job market of Thailand's economy. The study of the labor skills development could be summarized in 4 points 1 . Creating labor 2. Creating a quality choice. 3. Creating an information system for decision making quality. 4. Creating participation.

\section{Concept and Education Administration and Vocational Management}

Educational Administration is the operation of the individual segments to improve the quality of ideas, knowledge, ability, and a good man (Pintupan, 2006). Theories and concepts of educational administration require the application of knowledge. The theory and practice to get used to the situation, and environment management will look like art. There are four key factors that are important to management, called 4M including Men, Money, Material, and Management (Tharasrisuit, 2005: 16). Vocational school management means the career study, professional training, skilled training and practitioners with expertise related to the profession for using the ability in terms of both self-employed and employed (Vocational Education Commission, 2008: 33). Today, vocational schools produce graduates not in accordance with the job market and the resulting bad image affects the students in vocational schools, in spite of the companies need to hire more vocational graduates. The shortage of labor workers who graduate from vocational schools is in crisis (Chalamwong, 2014).

\section{Marketing Strategies}

There are concepts and theories of the marketing mix of the $8 \mathrm{P}$ model. The modern marketing strategy, the marketing mix, must have the concept of Integrated Marketing Communication, IMC, by studying the behavior of modern consumers which changes dramatically, Especially, the segmentation of the market. This cannot be divided by using traditional marketing. The concept is similar to branding, which in the first part of the concept is a guide to the business and causes of buying behavior. The other documents are related to assist in the marketing plan in a relevant manner to marketing.

In a business which is related to marketing, the relationship between the perception of the brand and the impact of marketing can be measured by sales or value evaluation (Silverman et al., 1999).

The Study Related With Vocational Schools Found That Variables in managing private vocational schools include the budget of private vocational schools, compensation and qualification, curriculum, quality of graduates, personal practical skills and their decision making abilities, community relations and local society, physical characteristics and location, network construction and participation. A variable of the establishment includes the process of evaluation, which reveals significant differences between the teacher and developers. Sometimes, the evaluation should be scheduled the training for evaluation (Kaslow et al., 2007; Kane, 2008; Johnston, 2004). Variables with educational establishments are of paramount importance in two sectors, which cooperate together. To be able to jointly solve the problem, because the problem cannot be resolved by one organization alone, can be summarized in a particular topic or covariance. For example, the location, physical characteristics and evaluation, and public relations, which are very important in today's world. It will be established by the well-known organizations including many schools, both public and private (Pahae, 2012). Network construction and participation is a highlight of vocational schools that is needed to forward graduates into work or participation in cooperation with management during study (Kaewcharoen, 2014).

\section{Research Methodology}

This research used a secondary source from the literature review of the theory of educational administration and marketing concepts. In addition, the research accumulated the primary population data by purposive sampling from ten southern private educational institutions and ten industrial establishments with semi-structured interviews. It was a major qualitative data collection. Moreover, this research used quantitative data collection by using a sample set-up table of Krejcie and Morgan (1970: 608-609). The researcher collected data from 402 questionnaires, including 46 private vocational schools and 356 industrial establishments. This research used a purposive sample, which is based on the growth rate and expansion of industry during the year 2015. The research period is from July to December 2015. (Source: Federation of Industries, 2014) The Table 1 shows information consistent with research objectives. Research Methodology Step is shown in Table 2 .

Table 1: Setting sample size used for store data of research.

\begin{tabular}{lllllll}
\hline Province & \multicolumn{3}{c}{ Population } & \multicolumn{2}{c}{ Qualitative Sampling } & \multicolumn{2}{c}{ Quantitative Sampling } \\
& Institute & Employer & Institute & Employer & Institute & Employer \\
\hline Nakhonsrithammarat & 19 & 2,176 & 5 & 3 & 46 & 356 \\
Songkhla & 13 & 2,464 & 3 & 5 & & \\
Suratthani & 5 & 1,345 & 2 & 2 & & \\
Total & & & 10 & 10 & & \\
\hline
\end{tabular}


Table 2: Research Methodology Step

\begin{tabular}{|c|c|c|c|c|}
\hline Step & Operations & Resources & Tools & Remarks \\
\hline 1. Survey & $\begin{array}{l}\text { Market Survey for the needs of } \\
\text { service users and providers. }\end{array}$ & $\begin{array}{l}\text { 1. } 10 \text { establishments } \\
\text { 2. } 10 \text { Pivate vocational } \\
\text { schools }\end{array}$ & $\begin{array}{l}\text { Interview } \\
\text { form }\end{array}$ & $\begin{array}{l}\text { A survey using qualitative } \\
\text { variables. }\end{array}$ \\
\hline $\begin{array}{l}\text { 2. Analysis of } \\
\text { survey data }\end{array}$ & $\begin{array}{l}\text { 1. Analysis of data from the } \\
\text { interview } \\
\text { 2. Create a Questionnaire } \\
\text { 3. Data was collected by } \\
\text { questionnaire }\end{array}$ & $\begin{array}{l}\text { 1. } 356 \text { establishments } \\
\text { 2. } 46 \text { Pivate vocational } \\
\text { schools }\end{array}$ & $\begin{array}{l}\text { Interview } \\
\text { form }\end{array}$ & $\begin{array}{l}\text { - Summary data } \\
\text { - Setting Indicators }\end{array}$ \\
\hline $\begin{array}{l}\text { 3. Grouping } \\
\text { elements }\end{array}$ & $\begin{array}{lr}\text { Grouping } & \text { elements } \\
\text { byusingExploratory } & \text { Factor } \\
\text { Analysis, EFA } & \\
\end{array}$ & same as step 2 & Questionnaire & Elements and Indicators \\
\hline 4. Model & $\begin{array}{l}\text { Confirmatory factor analysis } \\
\text { (CFA) }\end{array}$ & $\begin{array}{l}\text { 1. Establishments } \\
\text { 2. Private vocational } \\
\text { schools }\end{array}$ & & $\begin{array}{l}\text { The } \\
\text { Market-Oriented } \\
\text { Management Style of Private } \\
\text { Vocational Schools } \\
\text { in Complying with the Labor } \\
\text { Market }\end{array}$ \\
\hline
\end{tabular}

$\underline{\text { Table 3: important parameter and Indicators }}$

\begin{tabular}{|c|c|c|c|c|}
\hline Factor & Indicator & $\begin{array}{c}\text { Rating } \\
\text { schedule }\end{array}$ & Alpha & $\begin{array}{l}\text { Item-Total } \\
\text { correlation }\end{array}$ \\
\hline $\begin{array}{l}\text { 1. The standard set by the } \\
\text { school principals. }\end{array}$ & $\begin{array}{l}\text { S1: Establishments have joined to set the graduate and school } \\
\text { standard. } \\
\text { S2:Establishments should havea learner standard } \\
\text { S3:Co-management skills, professional training of students. } \\
\text { S4:The opportunity for students to get internships and } \\
\text { coaching } \\
\text { S5: Setting learning courses together with schools }\end{array}$ & $\begin{array}{c}5 \text { points } \\
\text { Likert } \\
\text { Schedule }\end{array}$ & .841 & $\begin{array}{l}.690 \\
.721 \\
.685 \\
.489 \\
.649\end{array}$ \\
\hline $\begin{array}{l}\text { 2. Evaluation from the } \\
\text { employer. }\end{array}$ & $\begin{array}{l}\text { E6:Employers are involved with graduate assessments } \\
\text { E7:Employers are involved in career testing standardization of } \\
\text { student } \\
\text { E8: The employment evaluation, the ability to solve problems. } \\
\text { E9:The employment evaluation leadership in terms of } \\
\text { assertive decision making } \\
\text { E10: Employers have professional testing of candidates. }\end{array}$ & & .814 & $\begin{array}{l}.656 \\
.679 \\
.736 \\
.678 \\
.296\end{array}$ \\
\hline $\begin{array}{l}\text { 3. Location of educational } \\
\text { institutions in view of the } \\
\text { employer and physical } \\
\text { environment. }\end{array}$ & $\begin{array}{l}\text { L11:Schools have a good surrounding environment } \\
\text { L12:The atmosphere in school, pleasantness, convenience, } \\
\text { and cleanliness } \\
\text { L13: Schools have channel to communications, comfort, } \\
\text { safety, and transportation. } \\
\text { L14: Establishments and factories located in areas close to the } \\
\text { school. } \\
\text { L15: Schools have annual hygiene monitoring } \\
\text { L16:Schools have strong and safe buildings }\end{array}$ & & .758 & $\begin{array}{l}.634 \\
.613 \\
.581\end{array}$ \\
\hline $\begin{array}{l}\text { 4. Networking and } \\
\text { participation. }\end{array}$ & $\begin{array}{l}\text { N17:The employer has created a network with other } \\
\text { partnerships, especially with schools } \\
\text { N18:The employert has created a network with other } \\
\text { partnerships } \\
\text { N19:Employers have employees attending events with other } \\
\text { organizations } \\
\text { N20: The establishment of school activities. } \\
\text { N21:Employer support for schools in terms of media and tools } \\
\text { for learning and practical skills }\end{array}$ & & .854 & $\begin{array}{l}.738 \\
.723\end{array}$ \\
\hline
\end{tabular}

N22: Evaluation of vocational students 


\begin{tabular}{|c|c|c|c|c|}
\hline Factor & Indicator & $\begin{array}{c}\text { Rating } \\
\text { schedule }\end{array}$ & Alpha & $\begin{array}{l}\text { Item-Total } \\
\text { correlation }\end{array}$ \\
\hline \multirow[t]{5}{*}{ 5. Public Relations } & $\begin{array}{l}\begin{array}{l}\text { I23:Promotion of information to vocational schools } \\
\text { continuously }\end{array} \\
\text { s }\end{array}$ & & .809 & .583 \\
\hline & I24:Promotetolocalcommunityandtheir participation & & & .632 \\
\hline & $\begin{array}{l}\text { I25: Event or exhibition with other organizations for public } \\
\text { relations. That is consistent with empirical data. The statistics } \\
\text { are consistent across all the criteria. }\end{array}$ & & & \\
\hline & I26: Promote a variety of channels with different formats. & & & .594 \\
\hline & I27:Analysis and selection of target groups for clear promotion & & & .528 \\
\hline
\end{tabular}

\section{Result}

After the researcher interviewed the managers of the business enterprises, the research found important parameters and metrics to manage the market as a base before the EFA shown in Table 3.

\section{Result from Exploratory Factor Analysis (EFA)}

Result from Exploratory Factor Analysis from the perspective of the establishment of the market-oriented management style of Private Vocational Schools in complying with the Labor Market in Southern Thailand contains five elements including:

1) Standardization and evaluation.

2) Network and public relations with the agency.

3) Public relations and schools.

4) The physical characteristics and location.

5) The participation of establishment to develop learners.

3) Results of confirmatory factor analysis (CFA)

To check the consistency of the developed empirical data on the management style of marketing research in private vocational schools to comply with the labor market in Southern Thailand, there are five elements and indicators. Setting up standardization and evaluation consists of many indicators including:

E7: Employers are involved in career testing standardization of students

E6: Employers are involved with graduate assessments

S1: Employers have joined to set the graduate and school standard.

S2: Employers should have a learner standard

E8: The employment evaluation, the ability to solve problems.

N22: Evaluation of vocational students.

L14: Establishments and factories located in areas close to the school.

This is consistent with empirical data by considering the statistics are consistent across all the criteria. $\chi^{2} / \mathrm{df}=28.098 / 13=2.16 \quad \mathrm{RMSEA}=.057, \quad \mathrm{CFI}=.986$,
$\mathrm{SRMR}=.027$. Considering the weight of the standard elements found that they were between $0.481-0.845$. These were statistically significant at all values.

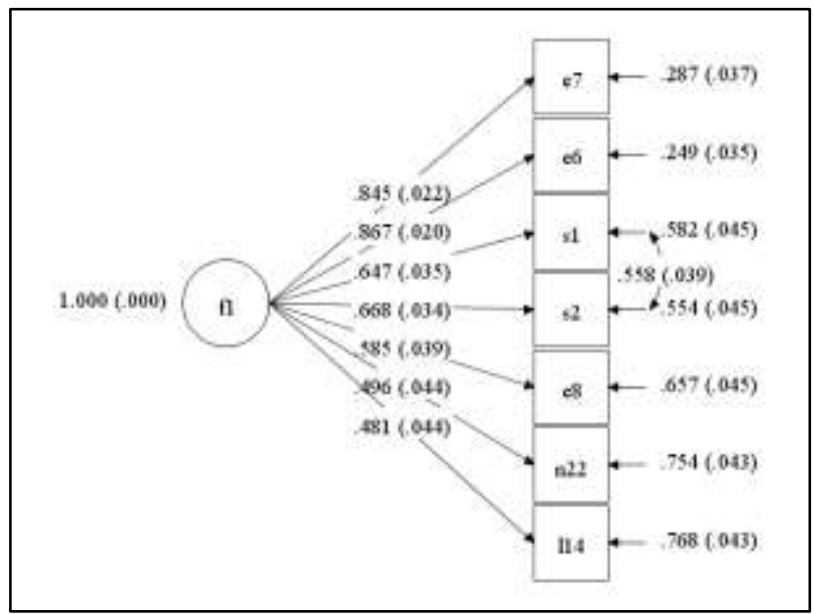

Fig. 1 Standardization and evaluation

Note Fig. 1 shows factor variance linked f1 to observable variables. E7, E6, S1, S2, E8, N22, L14 show values of Standardized Factor Loading. The observable variable is the Residual Variance which shows a relationship between the correlation values and Residual Variances.

Public relations with other organizations consisted of indicators including:

I23: Promotion of information to vocational schools continuously

N17: The employer has created a network with others partnerships, especially with schools

N18: The employer has created a network with other partnerships

I24: Promote to local communities and their participation

N19: Employers have employees attending events with other organizations

I25: Events or exhibitions with other organizations for public relations. That is consistent with empirical data. The statistics are consistent across all the criteria. 
There are $\chi^{2} / \mathrm{df}=3.79$. RMSEA $=.089, \mathrm{CFI}=.895$, SRMR=.02 Considering the weight of the standard elements found that they were between .632-.802. These were statistically significant at all values.

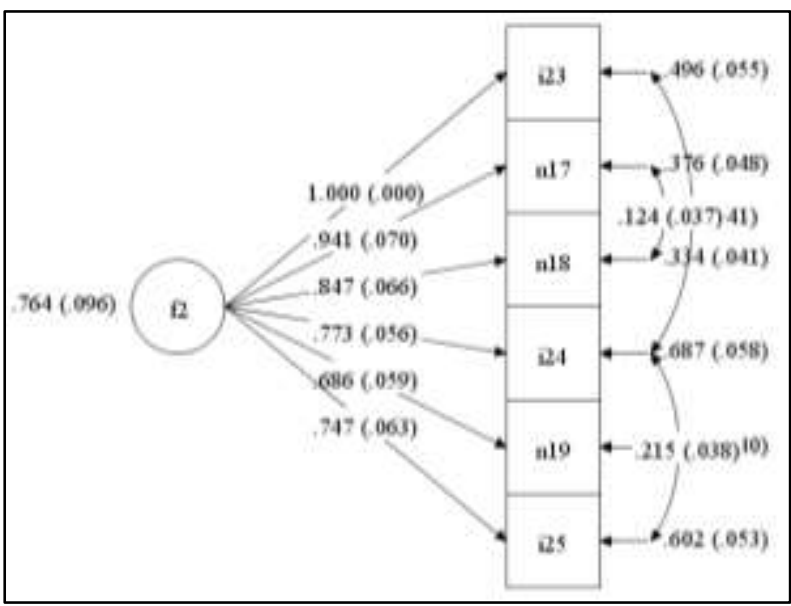

Fig. 2 Public relations with other organizations

Note: Fig. 2 shows factor variance linked to observable variables. I23, N17, N18, I24, N19 \& I25 show values of Standardized Factor Loading. The observable variable is the Residual Variance and it shows a relationship between the correlation values and Residual Variances.

Public relations with schools consisted of indicators including:

I26: Promote a variety of channels with different formats.

I27: Analysis and selection of target groups for clear promotion

N21: Employers support schools in terms of media and tools for learning and practical skills.

N20: The establishment of school activities.

E9: The employer evaluates leadership in terms of assertive decision making

This is consistent with empirical data on all levels by $\chi^{2}$ $=1.078, \mathrm{p}=.8977$, RMSEA=.000, CFI=1.00, SRMR=.007. Considering the weight of the standard elements found that they were between $.590-.755$. These were statistically significant at all values.

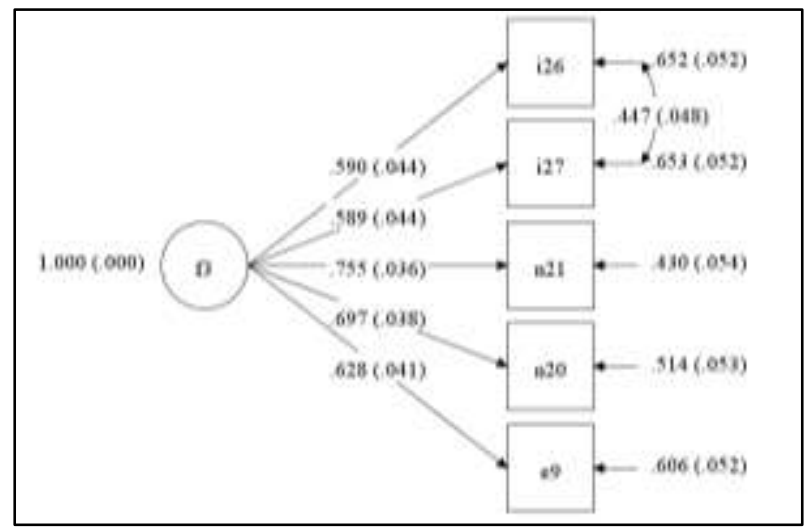

Fig. 3 Promoted in schools
Note: Fig. 3 shows factor variance linked to observable variables. I26, I27, N21, N20 \& E9 show values of Standardized Factor Loading. The observable variable is the Residual Variance and it shows relationship between the correlation values and Residual Variances.

Determining physical characteristics and location consisted of these indicators:

L12: The atmosphere in school, pleasantness, convenience, and cleanliness.

L11: Schools have a good surrounding environment

L13: Schools have channels to communications, comfort, safety, and transportation.

L16: Schools have strong and safe buildings.

L15: Schools have annual hygiene monitoring.

Research found that these were consistent with empirical data on the acceptable level by $\chi^{2} / \mathrm{df}=3.57$, RMSEA $=.085$, $\mathrm{CFI}=.980, \mathrm{SRMR}=.027$. Considering the weight of the standard elements, the research found that they were between $.415-.804$ these were statistically significant at all values.

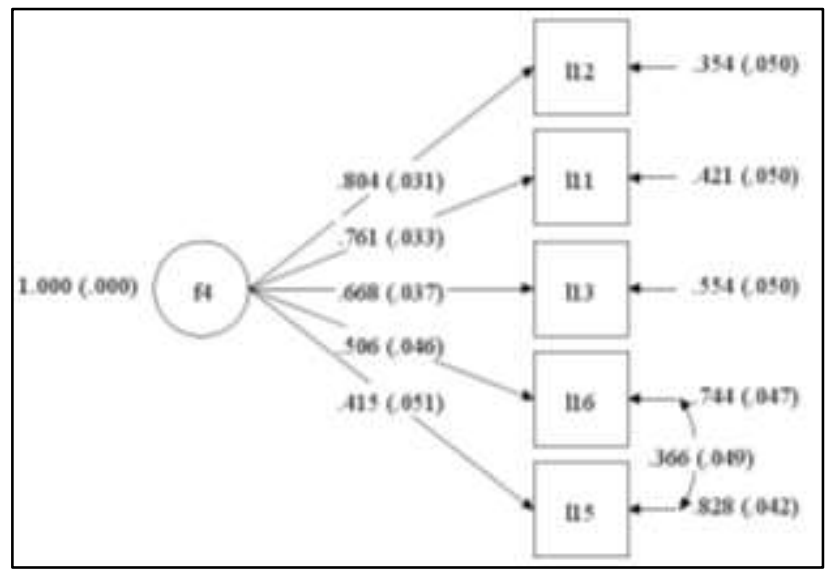

Fig. 4 Determining the physical characteristics and location

Note: Fig. 4 shows factor variance linked to observable variables. L12, L11, L13, L16 \& L15 show values of Standardized Factor Loading. The observable variable is the Residual Variance and it shows relationship between the correlation values and Residual Variances.

The participation of establishments to develop learners' standards consisted of these indicators:

S4: The opportunity for students to get internships and coaching.

S5: Setting learning courses together with schools.

S3: Co-management skills, professional training of students.

E10: Employers have professional testing of candidates. 
Research found that there were consistent with empirical data on the acceptable level. The statistics are consistent across all the criteria. $\chi^{2} / \mathrm{df}=.758, \mathrm{p}=.384$, $\mathrm{RMSEA}=.000, \mathrm{CFI}=1.000, \mathrm{SRMR}=.009$ Considering the weight of the standard elements, the research found that they were between $.376-.748$. These were statistically significant at all values.

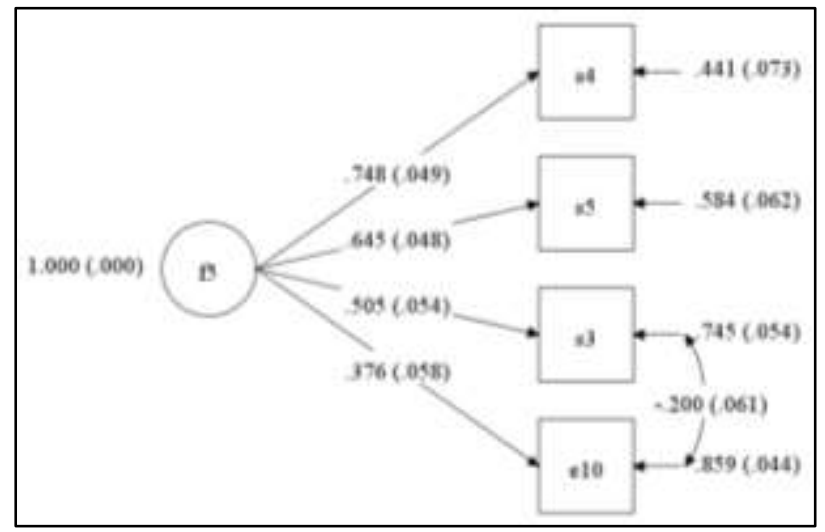

Fig. 5 The participation of establishments to develop learner's standards.

Note: Fig. 5 shows factor variance linked to observable variables. S4, S5, S3 \& E10 show values of Standardized Factor Loading. The observable variable is the Residual Variance and it shows relationship between the correlation values and Residual Variances.

\section{Discussion}

Researchers have discovered the issues that need to be discussed, focusing on discussing the results of research to answer specific research purposes. The findings stated that the form of education-oriented marketing of private vocational school in complying with the Labor Market in Southern Thailand, relied on 5 components. Each component complied with the education marketing management model related to the indicator, which shows how to manage the components. Such indicators, this research explains as follow:

First component: The standard setting and assessment by employers. The evaluation system by employers is of great interest for employees. The schools applied those for a quality management system (Ivy and Naude, 2004). The evaluation will create the appropriate indicators that the organization is required to accept the results of operations (Bellis-Jones, 1989; Bhargava et al., 1994; Bolton, 2004; Blattberg and Deighton, 1996). Evaluation of education and setting learner standards should be consistent with the professional standards in the real world. (Gulikers, Bastiaens and Kirschner, 2004; Kaslow et al., 2007) Assessing and defining professional standards, in particular the specific assessment, can only be the result of a psychological framework, these criteria are accurate and transparent (Linn et al., 1991; Messick, 1994). Professional standards were assessed and defined by assessing the specific talents related to psychological studies. These frameworks are considered valid and transparent criteria, the features and the quality of education as well as academic offerings. The experience of learners can be evaluated in a good manner (Hollensen, 2003:16). It can be concluded that the first component has the dimension of market manipulation that is connected directly to the product and also in relation to the dimensions of the price.

Second component: The elements related to public relations and information. Good communication increases professional skills and the ability to explain a basic quality of a good education (Kotler and Fox, 1995). Providing news to the employer, allows the school and the community to get to know their activities, especially with regard to its social responsibility activities, which events the school and community have been involved with together. The school will use this opportunity to improve public relations and networking in the community. The data obtained from communication and registration can be used to manage and maintain service levels and improve these aspects even further (Fjermestad and Romano, 2003; O'Learly et al., 2004). The indications related to networking and collaborating with other organizations or other schools. Building relationships with customers is an important part of the promotion; each entity will have a different aspect of relationship building. (Lovelock and Wright, 2000). In conclusion, findings from the second component has links in terms of marketing management, marketing promotion and in terms of public relations.

Third component: The element analysis and selection of target groups for public relations, to define communication channels. News strategy will result in a more positive image and positive attitude to the product (Rungreungpon, 2010). In addition, promotional channels help customers get access to product information, and target the market better. In conclusion, the indicator elements are linked to threedimensional marketing, which includes prospective customers and promotion. The researcher has used the concept of integrated marketing (4P) in the operation for the graduates to enter the workforce with sufficient quality and quantity.

Fourth component: The natural component which defines the physical characteristics and the location in the environment can be seen in relation to the geographical impact of marketing management. Physical characteristics are also linked to other services such as convenient transportation, ease of transport and easy access to consumers (Kannan and Srinivasan, 2009). Convenient transportation with ease to contact and secure a strategic position to build relationships with customers (Bhatt and Emdad, 2001). In conclusion, the indicator elements in the 
fourth component link with physical evidence presentation and distribution channels.

Fifth component: It is related to developing learner standards, vocational skills training and testing by professional establishments which are parts of the delivery system of products and services. It is a step to determine the activities and practices to enhance skills in planning and delivery (Kannan and Srinivasan, 2009). Skills are generally seen as appropriate to the different careers and the time required to learn those skills, as well as other capabilities such as personalized learning relationships with colleges relating to employment (Kearns, 2001). Employment skills of specific, or core groups, can be transfered to appropriate locations and professions at all levels of employment and in all levels of education. The quality worker skill is determined by the employer to fill vacant jobs (Overtoom, 2000). In conclusion, the indicator elements in the fifth component link in terms of the marketing process, the process steps in the proposed plan until with the end of the process with a great deal of time.

\section{Suggestion and Research Utilization}

The format of the components and indicators provide a guide to strengthen strategic planning. The research recommendations are divided into three parts: a suggestion for valuable academic works, suggestions for bringing research results to the user, and suggestions for further research. Details are below.

\section{A suggestion for valuable academic works}

This research has revealed new findings previously unknown. Components and indicator management in the marketing of private vocational school in order of weight of the composition and the indicators below.

1. The format and public relations to schools includes five indicators.

2. The format and public relations with other organizations consists of six indicators.

3. The format and setting up learner standardization and evaluation consists of seven indicators

4. The format and the participation of establishments to develop learners consists of four indicators.

5. The format to determine the physical characteristics and location consists of five indicators, and it can be integrated through the marketing main idea to create new knowledge.

\section{Research Utilization}

To guide the planning and marketing oriented style of private vocational school in the South of Thailand, the researchers suggest the following:

This research discovered how to manage schools, including private vocational curriculum, skills, practices and decisions, community and public relations, the physical characteristic and location, networking and participation, and public relations. It is crucial that the private vocational schools in the South should focus on the productivity of their students and allocate sufficient funds to the development and empowerment of the most vulnerable part to respond to the needs of public service, which is the employer. The quality of students is reflected by the quality of the education itself. In addition, the component relating to the remuneration and qualification is important. The findings of this study need to look back and focus on the primary incentive.

This research discovered a view of the establishment of the market-oriented management of private vocational schools include standardization and evaluation. Networking with other organizations and public relations related with schools determining physical characteristics and location. Considering the level of detail of the component indicators, it has been shown that establishments open to students in various aspects such as education can enhance cooperation with enterprises. Especially, education should be implemented using standardization and evaluation. Participation in the program is consistent with the needs of the employer. In particular, the way of cooperation or cooperation in the development of skilled labor in the process of reciprocals such as MOU.

\section{Suggestions for future research}

Further study is required to find the key to making the process commercially driven to effectively manage micro level factors, such as the level of individuals, factor group and employers as well as changes in economic, political and social policies, especially with regard to educational policies and the strategic management of the vocational education sector.

\section{References}

Akradate J and Sudaporn S (2013) Marketing Strategy of Private Vocational School in Thailand. Journal of Easthern Asia 3-2 July/December 2013 114-124

Bellis-Jones R (1989) Customer profitability analysis Management Accounting (UK) 67-2 26-28

Bhargava M, Dubelaar C and Ramaswami S (1994) Reconciling diverse measures of Performance: A conceptual Frame work and test of a methodology Journal of Business Research 31 235-246.

Bhatt GD and Emdad AF (2001) An analysis of the virtual value chain in electronic commerce. Logistics Information Management 14(1/2) pp $78-85$.

Blattberg RC and Deighton J (1996) Manage marketing by the customer equity test Harvard Business Review 74(JulyAugust) 136-144.

Bolton RN (2004) Linking marketing to financial performance and firm value Journal of Marketing 68(October) 73-75

Chalamwong (2014) Thailand Labor in A New Context: Vocational Education for The Nation TDRI Access dated 
20 October 2014 from:http://tdri.or.th/tdri-insight/thailabour-force.

Fjermestad J and Romano NCJ (2003) An Integrative Implementation Framework for Electronic Customer Relationship Management: Revisiting the General Principles of Usability and Resistance Proceedings of the 36th Hawaii International Conference on Systems Sciences.

Gulikers J, Bastiaens T and Kirschner P (2004) A five-dimensional framework for authentic assessment Educational Technology Research and Development 52 (3) 67-85.

Hollensen S (2003) Marketing Management: A Relationship Approach Harlow: Financial Times \& Prentice Hall Chapter 1.

Ivy J and Naude P (2004) Succeeding in the MBA marketplace: identifying the underlying factor, Journal of Higher Education Policy \& Management 26(3) 401-417.

Johnston B (2004) Summative assessment of portfolios: an examination of different approaches to agreement over outcomes Studies in Higher Education 29(3) 395-412.

Kaewcharoen (2014) Evaluation of the Dual Diploma Programs in Retail of Private Vocational School in Southern Region. Master Thesis, Faculty of Education Taksin University

Kane M T (2008) Terminology, emphasis, and utility in validity Educational Researcher 32(2) 78-82.

Kannan and Srinivasan (2009) A Service Marketing Perspective, Tourism Marketing MPRA Paper No. 14031 mpra.ub.unimuenchen.de.

Kaslow N J et al (2007) Guiding principles and recommendations for assessment of competence Professional Psychology: Research and Pratice 38 441-451

Kearns P (2001) Review of Research: Generic skill for the new economy NCVER Adelaide

Kotler P and Fox K (1995) Strategic marketing for Educational Institutions 2nd ed. Englewood cliffs N J: Prentice-Hall Chapter 1.

Krejcie V and Morgan DW (1970) Educational and Psychological Measurement. 608-609.
Linn RL, Baker E Land Dunbar SB (1991) Complex, performance-based assessment: Expectations and validation criteria. Educational Researcher 20(8) 15-21

Lipsey R and Lipsey G (1996) Economics 11thed. New York: Harper Collins Publishers.

Lovelock C and Wright L (2000) Principles of Service Marketing and Management $2^{\text {nd }}$ ed. Published by prentice Hall an imprint of Pearson Education Inc.

Messick S (1994) The interplay of evidence and consequences in the validation of performance assessments Educational Researcher 23(2) 13-23.

O'Learly C, Rao S and Perry C (2004) Improving Customer Relationship Management through Database/Internet Marketing. A Theory-building Action Research Project European Journal of Marketing 38 (3/4) 238-254.

Overtoom C (2000) Employability Skills: An Update, Center on Education and Training for Employment ERIC Digest No. 220.

Pahae (2012) Media and Technology for Education Prae Primary Education Service Area Office 2.

Pintupan (2006) The School Administrators and Building Relationships with The Community Faculty of Education. Naresuan University.

Reynolds JM (1982) Aphrodisias and Rome Journal of Roman Studies monograph 1 (London, 1982) A\&R.

Rungreungpon (2010) Marketing Concept Bangkok: Thammasat University

Silverman SN, Sprott DE and Pascal VJ (1999) Relating consumer-based sources of brand equity to market outcomes Advances in Consumer Research 26 352-8

Tharasrisuit (2005) Leadership and Ethics for Executive Education Bangkok: Ramkumhang University

Ungsujinda (2010) Components of Marketing Strategies that Affecting the Success of Private School Ph.D. Thesis, Management Program, Graduate School Christian University.

Wuteay (2009) Management Strategic of Private Vocational School in Chieng Mai 